\title{
In vitro and foliar spray evaluation of Verbena officinalis (L.), Erythrina mulungu (Mart. ex Benth.), Quassia amara (L.), Bidens pilosa (L.) and Plantago lanceolata (L.), extracts on Meloidogyne incognita (Kofoid \& White, 1919) Chitwood, 1949
}

\author{
Evaluación in vitro y aplicación foliar de Verbena officinalis (L.), Erythrina mulungu \\ (Mart. ex Benth.), Quassia amara (L.), Bidens pilosa (L.) y Plantago lanceolata (L.), \\ sobre Meloidogyne incognita (Kofoid \& White, 1919) Chitwood, 1949
}

\author{
Milena A. Ferrari Mateus ${ }^{1 *}$, Cacilda M. Duarte Rios Faria ${ }^{1}$, Renato V. Botelho ${ }^{1}$, \\ Rosangela Dallemole-Giaretta ${ }^{2}$, Silvana G. Martins Ferreira ${ }^{1}$, Welton L. Zaluski ${ }^{1}$
}

\begin{abstract}
This study aimed to evaluate the efficiency of aqueous extracts of five species of medicinal plant, Verbena officinalis (L.), Erythrina mulungu (Mart. ex Benth.), Quassia amara (L.), Bidens pilosa (L.) and Plantago lanceolata (L.) in vitro, and sprayed on tomato plants for the control of Meloidogyne incognita. In vitro experiments were conducted in growth chambers in acrylic ELISA plates. The treatments were doses of $0,10,20,30,40$ and $50 \mathrm{~g} \cdot \mathrm{L}^{-1}$ of different aqueous extracts. On the sixteenth day the number of second stage juveniles $\left(\mathrm{J}_{2}\right)$ hatched per treatment was evaluated. The results showed that aqueous extracts of $V$. officinalis, E. mulungu, Q. amara, B. pilosa and P. lanceolata, reduced the hatching of $M$. incognita, with the aqueous extract of $P$. lanceolata showing up to $100 \%$ reduction in hatching. The in vivo assay was conducted in a greenhouse. For this, four sprays of different extracts were applied to tomato shoots. According to the results of this test, none of the extracts were efficient at controlling $M$. incognita through foliar spraying. The efficiency of these extracts to control plant parasitic nematodes during in vivo tests should not be disregarded, however, further studies should be conducted to test different methods of application, doses or methods of extracting the active principles.
\end{abstract}

Key words: alternative control, Meloidogyne incognita, organic agriculture, nematicide.

\section{RESUMEN}

El objetivo del estudio fue evaluar la eficacia de los extractos acuosos de cinco especies de plantas medicinales, Verbena officinalis $(L$.), Erythrina mulungu (Mart. ex Benth.), Quassia amara (L.), Bidens pilosa $(L$.) y Plantago lanceolata $(L$.) in vitro, y se pulverizaron en las plantas de tomates para el control de Meloidogyne incognita. Los experimentos in vitro fueron realizados en cámaras de crecimiento en placas de ELISA de tipo acrílico. Los tratamientos fueron dosis de 0, 10, 20, 30, 40 y $50 \mathrm{~g} \cdot \mathrm{L}^{-1}$ de diferentes extractos acuosos. En el día dieciséis se evaluó el número de juveniles segunda etapa $\left(J_{2}\right)$ nacidos por tratamiento. Los resultados mostraron que los extractos acuosos de V. officinalis, E. mulungu, Q. amara, B. pilosa y P. lanceolata reducen la eclosión de los juveniles de M. incognita, y el extracto acuoso de $\mathrm{P}$. lanceolata mostró hasta $100 \%$ de reducción de la tasa de eclosión. El ensayo in vivo se realizó en un invernadero, y para ello, había cuatro pulverizaciones de diferentes extractos en los brotes de tomate. Según los resultados de esta prueba, ninguno de los extractos por pulverización foliar era eficaz en el control de M. incognita. Sin embargo, no se debe descartar la eficiencia de estos extractos en el control de nematodos parásitos de plantas, pero más estudios se llevan a cabo utilizando diferentes métodos de aplicación, las dosis o métodos de extracción de los principios activos de los extractos.

Palabras clave: alternativa de control, Meloidogyne incognita, agricultura orgánica, nematicida.

\section{Introduction}

The nematodes of the genus Meloidogyne Goeldi (1887), are some of the most important plant parasites, they have a wide geographical distribution, a huge host range and cause major damage to crops (Freitas et al., 2007). In the literature there are many methods described for the control of

\footnotetext{
1 Universidade Estadual do Centro-Oeste/ UNICENTRO, Campus CEDETEG, Departamento de Agronomia, Guarapuava, PR, Brasil. E-mail: miferrarimateus@gmail.com.*Autora para correspondência.

2 Universidade Tecnológica Federal do Paraná/UTFPR, Departamento de Agronomia, Pato Branco, PR, Brasil.
}

Fecha de Recepción: 21 Marzo, 2012.

Fecha de Aceptación: 18 Noviembre, 2012. 
nematodes (Ferraz et al., 2010). However, control of these plant parasites is still a difficult task, mainly due to the inherent limitations of these control methods (Neves et al., 2008). For example, the use of chemical nematicides increase production costs, and cause human and environmental risks (Campos et al. 1998). With this in mind many researchers over recent decades have been studying alternative methods of nematode control, such as the use of botanical extracts that have nematicidal properties (Ferris and Zheng, 1999; Oka et al., 2000; Neves et al., 2005).

Among the various plants studied for the preparation of nematicidal extracts, such as essential oils, Mucuna prurienses, Tagetes spp., Crotalaria spp., Azadirachta indica, Ricinus communis, the genus Brassica, several species of medicinal aromatic plants and many grasses have been the most commonly investigated (Ferraz et al., 2010).

An interesting feature in the use of botanical extracts for the control of parasitic plant nematodes, is that they can be applied via soil or foliar spray. Moreover, in several studies it has been found that the ground application of aqueous botanical extracts have shown positive results for the control of root-knot nematodes, as reported by Franzener et al. (2007); Javed et al. (2008); Gardiano et al. (2009) and Gardiano et al. (2010). When Franzener et al. (2007) applied aqueous extract of Tagetes patula flowers to the soil, at the concentration $0.05 \mathrm{~g} \cdot \mathrm{mL}^{-1}$, they found that the aqueous extract effected populations of $M$. incognita by reducing the number of galls, eggs in the tomato roots and second-stage juveniles $\left(\mathrm{J}_{2}\right)$ in soil, by $62.2 \%, 61.5 \%$ and $52.8 \%$, respectively. Javed et al. (2008) also observed reductions in the gall and egg numbers of $M$. javanica, when aqueous extracts of neem leaves where applied to the soil at doses of 1.5 to $3.0 \%$. The aqueous extract of lemon grass (Cymbopogon citratus (DC) Stapf) and leaves of Crotalaria mucronata $\mathrm{L}$., when applied to the soil at doses of and $0.2 \mathrm{~g} \cdot \mathrm{mL}^{-1}$, respectively, also showed the same nematicidal effect (Gardiano et al., 2009; Gardiano et al., 2010).

However, research on the application of plant extracts, mainly in the spray form to the shoot for nematode control is scarce (Gardiano et al., 2008a). In this context, the study aimed to assess the nematicide potential, in vitro, of Verbena officinalis (L.), Erythrina mulungu (Mart. Ex Benth.), Quassia amara (L.), Bidens pilosa (L.) and Plantago lanceolata (L.) aqueous extracts, on the hatching of $M$. incognita and in vivo, on tomato plants with extracts applied through a foliar spray in the greenhouse also against M. incognita.

\section{Material and Methods}

In vitro test: We tested the aqueous extracts of V. officinalis, E. mulungu, Q. amara, B. pilosa and $P$. lanceolata, at concentrations of $0,10,20$, 30,40 or $50 \mathrm{~g} \cdot \mathrm{L}^{-1}$. For the extract preparation we used the methodology described by Ferris and Zeng (1999). For this, $0.5 \mathrm{~g}$ of each dried herb, chopped to approximately $1 \mathrm{~cm}$ in length, was added separately to its own $600 \mathrm{~mL}$ capacity beaker, $10 \mathrm{~mL}$ of tap water was added to each, and allowed to rest for 24 hours in the dark at $25^{\circ} \mathrm{C}$. After this period the aqueous extracts of the plant species were filtered separately through double layers of cheesecloth. The assay was mounted on a ELISA polystyrene microplate. In each well of the plate was placed separately $100 \mathrm{~mL}$ of an aqueous suspension containing 50 eggs of $M$. incognita and $100 \mathrm{~mL}$ of the respective extracts. To the control treatment was added only tap water. The plates were kept in growth chambers for 15 days at $25 \pm 1{ }^{\circ} \mathrm{C}$ in the dark. On the sixteenth day the number of secondstage juveniles $\left(\mathrm{J}_{2}\right)$ hatched in each treatment was evaluated. The experiment was conducted in a completely randomized design with six repetitions. The experimental unit was represented by a well of ELISA microplate. Data were subjected to analysis of variance and when significant were performed the analysis regression at 5\% probability using the statistical program Sisvar 5.0.

In vivo test: This test was conducted from January to March of 2011 during which the average temperature in the greenhouse was $24.5^{\circ} \mathrm{C}$, while the mean minimum and maximum were $18.6^{\circ} \mathrm{C}$ and $30.5^{\circ} \mathrm{C}$, respectively. The test was mounted using polypropylene pots of 1.0 liter capacity, containing a mixture of soil and sand at a 2:1 (v:v) ratio, previously autoclaved for one hour at $120{ }^{\circ} \mathrm{C}$ at 1 atm. In each pot one tomato seedling cv. Santa Clara $\circledR$ (Isla ${ }^{\circledR}$, Brazil) was planted for 25 days. After which each plant was inoculated with an aqueous suspension containing 3000 eggs of M. incognita. After inoculation of the plants with the nematode, the tomato plants were sprayed with the aqueous extracts tested in the in vitro assay at a concentration of $100 \mathrm{~g} \cdot \mathrm{L}^{-1}$, for this $100 \mathrm{~g}$ of shoots of each 
tested plant were added separately to $1000 \mathrm{~mL}$ of tap water at ambient temperature. Using a hand sprayer (Brasutil mark Disma ® PD350, Brazil) the extracts were applied to tomato plants until the runoff point was reached. For the preparation of aqueous extract, the same methodology described in the in vitro assay was used. However, in this study, the amount of each plant material used was $100 \mathrm{~g} \cdot \mathrm{L}^{-1}$. To avoid the extracts coming in contact with the soil, each pot was sealed with a transparent plastic. The spraying was carried out in the late afternoon, according to the methodology described by Bala and Sukul (1987). During the experimental period four sprays were conducted, with a two week interval between each. The statistical design was completely randomized with seven repetitions per treatment. Two treatments one where only water was added and one which was treated with the nematicide carbofuran / Furadan $₫$ (FMC químca, California / USA). The nematicide was applied in the soil, only at the time of planting, as in agronomic recommendations set by the manufacturer.

Sixty days after the inoculation of tomato plants with the nematode, the height of the shoot, the fresh mass of the shoots and roots, gall numbers, number of egg masses and eggs per root system were evaluated. For the assessment of the number of egg masses, the methodology described by Rocha et al. (2005) was used.

Data were subjected to variance analysis and when significant, the means were compared using Duncan's test at $5 \%$ probability, using the statistical package "Statistica" (Statsoft).

\section{Results and Discussion}

All doses of the aqueous extracts of $V$. officinalis, E. mulungu, Q. amara, B. pilosa and P. lanceolata, tested in vitro, reduced the hatching percentage of $\mathrm{J}_{2} M$. incognita when compared to the control (Figures 1 A, B, C, D and E).

The aqueous extract of $V$. officinalis reduced the hatching percentage of $\mathrm{J}_{2} M$. incognita by $17.5 \%$, $51.3 \%, 63.7 \%, 92.1 \%$ and $93.5 \%$ at the doses 10,20 , 30,40 and $50 \mathrm{~g} \bullet \mathrm{L}^{-1}$, respectively, when compared with the control treatment (Figure 1A). The aqueous extract of Q. amara, at doses of 10, 20, 30, 40 and $50 \mathrm{~g} \cdot \mathrm{L}^{-1}$ reduced the hatching of the nematode $\mathrm{J}_{2}$ by $8.80 \%, 22.6 \%, 33.20 \%, 44.31 \%$ and $49.5 \%$, respectively (Figure 1B). The aqueous extract of B. pilosa reduced hatching by $27.5 \%, 31.8 \%, 73.2 \%$,
$76.7 \%$ and $99.7 \%$ at the doses 10, 20, 30, 40 and $50 \mathrm{~g} \cdot \mathrm{L}^{-1}$, respectively (Figure $1 \mathrm{C}$ ). The aqueous extract of $P$. lanceolata at a dose of $10 \mathrm{~g} \cdot \mathrm{L}^{-1}$, showed a $68.6 \%$ reduction in hatching of $\mathrm{J}_{2}$ of M. incognita when compared with the control. While, the doses of $20,30,40$ and $50 \mathrm{~g} \bullet \mathrm{L}^{-1}$ reduced hatching by more than $92.7 \%$. The aqueous extract of E. mulungu at doses of 10 and $20 \mathrm{~g} \bullet \mathrm{L}^{-1}$ decreased hatching by $21.1 \%$ and $35.5 \%$. While, at doses of 30,40 or $50 \mathrm{~g} \mathrm{~L}^{-1}$ a reduction of $65.1 \%, 80.0 \%$ and $78.8 \%$, were found respectively, compared to the control treatment.

Similar results in nematodes control were also found by other authors when using the same family of $V$. officinalis (Verbenaceae) plants. Elbadri et al. (2008), studying the medicinal plant Lantana camara (L.), family Verbenaceae, found that the methanol extract of this plant, showed a nematicidal effect against $M$. incognita causing $73.3 \%$ mortality of juveniles. This fact probably occurs because $V$. officinalis has anthelmintic activity (Lorenzi and Matos, 2008).

Other plants of the same family such as E. $m u$ lungu (Fabaceae) have shown nematicidal activity, as is the case of Mucuna spp. which contains compounds such as L-Dopa (3,4-dihydroxyphenylalanine), which is a substance with strong nematicidal effects (Ferraz et al., 2010). Other compounds with nematicidal activity were isolated from aerial parts of plants of Mucuna aterrima (Pipper and Tracy), such as triacontanyl tetracosanoate tiacontil tetracosanate and triacontanol, which showed nematicidal activity against $M$. incognita race 3 (Nogueira et al., 1996). Perhaps because E. mulungu also belongs to Fabaceae family, some of these substances occur in the plant and provide the nematicidal properties presented in this study, which could explain the reduction in percentage of $M$. incognita $\mathrm{J}_{2}$ hatchings.

In studies performed in vitro using the medicinal plant Trigonella foenum-graecum (L.), that also belongs to the Fabaceae family, Elbadri et al. (2008) found that the aqueous extract of this plant, showed a nematicidal effect toward $M$. incognita causing $73 \%$ mortality when juveniles were exposed to extractsfor 72 hours.

While investigating other species of genus Plantago, Insunza et al. (2001), found that the aqueous extract at $0.2 \mathrm{~g} \bullet \mathrm{mL}^{-1}$, obtained from roots of Plantago major (L.), caused $85.4 \%$ immobility in juvenile Xiphinema americanum. The nematicidal effect of plants belonging to the genus Plantago 

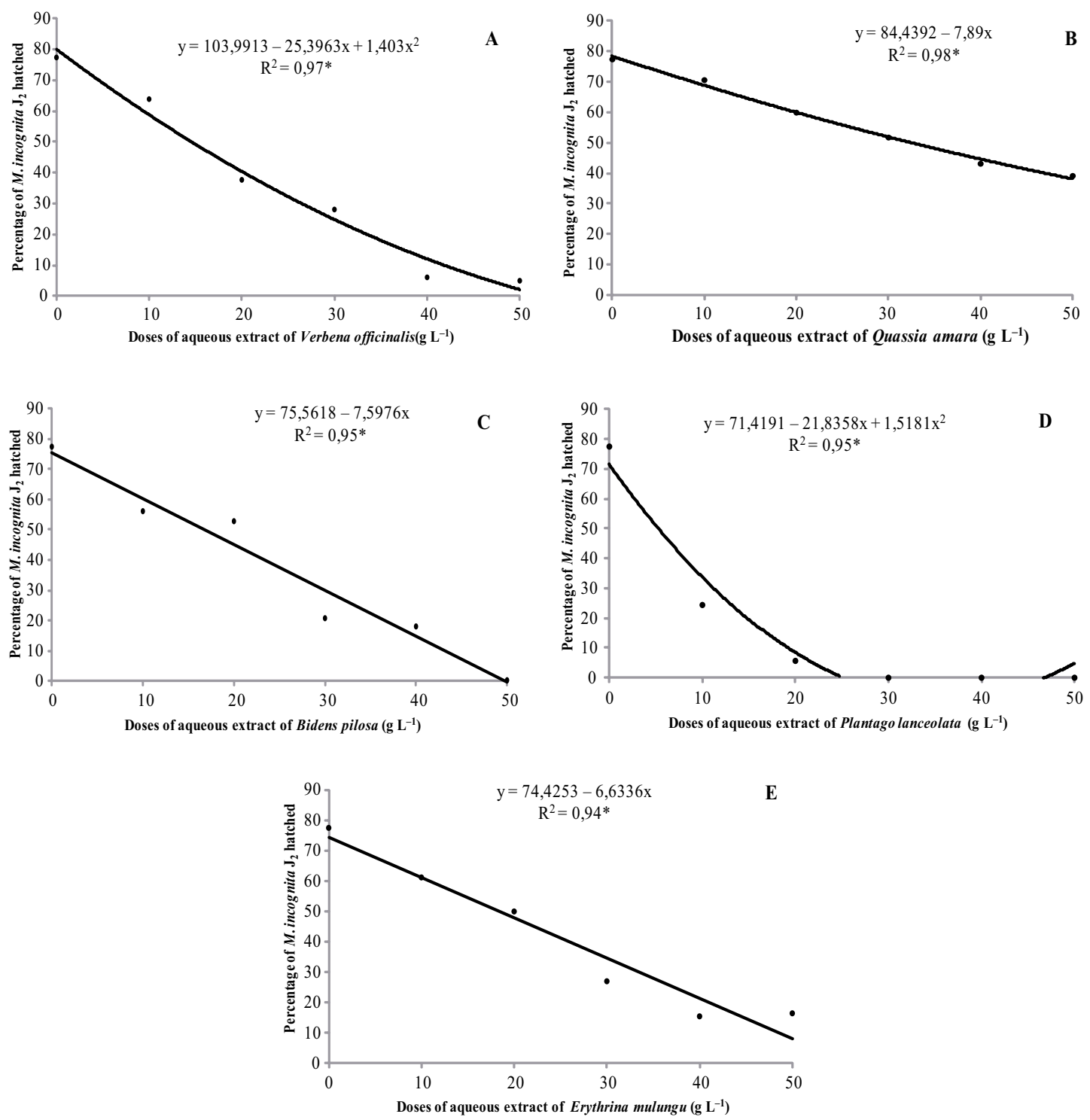

Figure 1. In vitro effect of aqueous extracts of Verbena officinalis (A), Quassia amara (B), Bidens pilosa (C), Plantago lanceolata (D) and Erythrina mulungu (E), on hatching of $\mathrm{J}_{2}$ Meloidogyne incognita. Guarapuava, Paraná, Brazil, 2011.

was also demonstrated by Meyer et al. (2006), by using a methanol extract of Plantago rugelii (L.) they observed a $64 \%$ reduction in the hatching of $M$. incognita juveniles. It should be noted that in this test, the aqueous extract of $P$. lanceolata presented a more toxic extraction of active ingredients when compared to the results obtained with the use of methanol extract of $P$. rugelii presented earlier. Further to this according Silva et al. (2008), the use of aqueous extracts in field conditions, for environmental reasons, are more suitable than those of methanol.

Bidens pilosa is a plant belonging to the Asteraceae family, a number of plants belonging to this family, have a broad spectrum of polyacetylenes with broad biological activity, including nematicidal activity, according Chitwood et al. (2002). It is possible that the results obtained in this assay may be due to the presence of these compounds in the B. pilosa extract. 
Table 1. Fresh shoot mass, shoot height of tomato plants, fresh root mass, number of galls, number of eggs and number of egg masses of Meloidogyne incognita after the spraying of tomato plant shoots with aqueous extracts of Verbena officinalis, Quassia amara, Bidens pilosa, Plantago lanceolata and Erythrina mulungu. Guarapuava, Paraná, Brazil, 2011.

\begin{tabular}{lccccc}
\hline Treatment & $\begin{array}{c}\text { Fresh shoot mass } \\
(\mathrm{g})\end{array}$ & $\begin{array}{c}\text { Shoot height of } \\
\text { tomato plants } \\
(\mathrm{cm})\end{array}$ & $\begin{array}{c}\text { Fresh root mass } \\
(\mathrm{g})\end{array}$ & $\begin{array}{c}\text { Number of galls } \\
\text { per root }\end{array}$ & $\begin{array}{c}\text { Number of eggs } \\
\text { per root }\end{array}$ \\
\hline Verbena officinalis & $5.37 \mathrm{~b}$ & $24.46 \mathrm{ab}$ & $5.43 \mathrm{ab}$ & $395 \mathrm{a}$ & $236,364 \mathrm{~ns}$ \\
Plantago lanceolata & $5.97 \mathrm{ab}$ & $25.31 \mathrm{ab}$ & $4.34 \mathrm{bcd}$ & $372 \mathrm{a}$ & 207,42 \\
Erythrina mulungu & $3.60 \mathrm{bc}$ & $22.66 \mathrm{~b}$ & $3.36 \mathrm{de}$ & $238 \mathrm{~b}$ & 184,117 \\
Quassia amara & $4.13 \mathrm{bc}$ & $22.37 \mathrm{~b}$ & $3.67 \mathrm{~cd}$ & $198 \mathrm{~b}$ & 193,721 \\
Bidens pilosa & $2.37 \mathrm{c}$ & $17.51 \mathrm{c}$ & $1.99 \mathrm{e}$ & $198 \mathrm{~b}$ & 151,414 \\
Control (water) & $7.78 \mathrm{a}$ & $27.59 \mathrm{a}$ & $6.67 \mathrm{a}$ & $400 \mathrm{a}$ & 220,244 \\
Control (Carbofuran) & $5.12 \mathrm{~b}$ & $26.01 \mathrm{ab}$ & $5.09 \mathrm{abc}$ & $143 \mathrm{c}$ & 139 \\
\hline CV (\%) & 40.71 & 16.12 & 31.94 & 30.89 & 38 \\
\hline
\end{tabular}

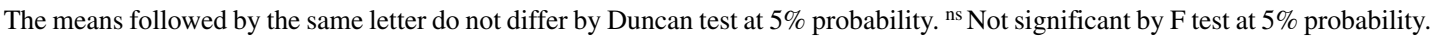

Many authors have found nematicidal activity during in vitro experiments, by plants of the genus Tagetes spp. (Asteraceae). Bharadwaj and Sharma (2007), found that during in vitro experiments, that the doses of $6.6 \%, 10 \%, 13.3 \%, 16.6 \%$ and $20 \%$ of the aqueous extract derived from leaves of T. patula, inhibited the hatching of M. incognita $\mathbf{J}_{2}$ by $100 \%$ after 48 hours exposure.

Insunza et al. (2001), observed an in vitro nematicidal effect of aqueous extracts from the aerial parts and roots of T. erecta and T. patula at a dose of $0.25 \mathrm{~g} \cdot \mathrm{mL}^{-1}$, on the nematode Xiphinema americanum and verified the presence of nematostatic or nematicidal effect after 24 hours exposure. Assessing the in vitro activity of aqueous extract obtained from the leaves of the plant $T$. erecta at doses of 5,25 and $50 \mathrm{~g} \cdot \mathrm{L}^{-1}$, Hasabo and Noweer (2005), found $67 \%, 72 \%$ and $100 \%$ mortality of $\mathrm{J}_{2}$ M. incognita, respectively.

The nematicidal effect observed in the medicinal plant $Q$. amara, may be due to the presence of compounds termed quassinoids, which are degraded tetracyclic or pentacyclic triterpenoids. The chaparrinona quassinoids, Klaineanone, glaucarubolone found in the seeds of the plant Hannoa undulata (Simaroubaceae) inhibited the penetration of $\mathrm{J}_{2}$ $M$. javanica into tomato plants at a concentration of $5.1 \mathrm{mg} \cdot \mathrm{mL}^{-1}$ (Chitwood 2002).

The spraying of different aqueous extracts in vivo, on tomato plants affected negatively the vegetative growth of the plants during this assay (Table 1). Foliar spray of aqueous extracts of V. officinalis, E. mulungu, Q. amara, B. pilosa and the control (carbofuran) decreased by $31.0 \%, 53.7 \%$,
$47.0 \%, 70.0 \%$ and $34.2 \%$ respectively, the fresh mass of tomato shoots. The extracts of $E$. mulungu, $Q$. amara, B. pilosa reduced the growth of tomato plants, when compared with the control treatment.

Furthermore, this study found reductions of $18.0 \%, 19.0 \%$ and $36.5 \%$, of the height of tomato plants when sprayed with the aqueous extracts of the E. mulungu, $Q$. amara, B. pilosa respectively. The fresh mass of roots was reduced by $35.0 \%$, $49.6 \%, 45.0 \%$ and $70.2 \%$, compared with the control (water), when the tomato plants were sprayed with the aqueous extracts E. mulungu, Q. amara, B. pilosa e $P$. lanceolata, respectively. It can be seen therefore in this assay, the occurrence of phytotoxicity in tomato plants with a spray of aqueous extracts of the E. mulungu, Q. amara, B. pilosa.

Similar results were found by Lopes et al. (2005); Gardiano et al. (2008a) and Gardiano et al. (2008b), while researching different extracts, and their effects on vegetative growth of tomato plants infected with Meloidogyne spp.

Lopes et al. (2005) also found reductions of $32.5 \%, 26.5 \%$ and $29.7 \%$, when they applied foliar sprays of aqueous extracts of Ocimum basilicum leaves and leaves and seeds of Mucuna spp., respectively. According to Gardiano et al. (2008a), when tomato plants infected with $M$. javanica were sprayed with $10 \%$ aqueous extracts of either Chrysanthemum parthenium, Arctium lappa, Calopogonium mucunoides, Cymbopogon citratus, Baccharis trimera, Equisetum sp., Mentha spp. and Ricinus communis, a reduction was observed in fresh root mass compared with the control treatment, which was sprayed only with water. 
Researching the effect of spray dyes obtained from Azadirachta indica, Petiveria alliacea, Melia azedarach, Plectranthus barbatus, Canavalia ensiformis or Ricinus communis on tomato plants infected with M. javanica, Gardiano et al. (2008b) found that these treatments did not significantly influence the mass of the root systems of the plants.

Spraying tomato plants with aqueous extracts of the E. mulungu, Q. amara, B. pilosa. affected the infectivity of nematodes compared with the control (water) (Table 1), however, showed less effect than was observed with the use of the synthetic nematicide. The application of aqueous extracts of E. mulungu, $Q$. amara, B. pilosa decreased the number galls observed when compared with the control (water) by $40.5 \%, 50.5 \%$ and $50.5 \%$, respectively. While carbofuran reduced gall numbers by $64.2 \%$. As for the number of eggs and egg masses of $M$. incognita, it was found that there was no statistical difference between treatments (Table 1).

Gardiano et al. (2008b) found no satisfactory results for reducing gall and egg numbers of $M$. javanica, when tomato plants were sprayed with dyes of Azadirachta indica, Petiveria alliacea, Melia azedarach, Canavalia ensiformis, Plectranthus barbatus and Ricinus communis.

Gardiano et al. (2008a) also found no significant results in reducing galls and reproduction of $M$. javanica, when tomato plants were sprayed with aqueous extracts, at a dose of $10 \%$, obtained from the aerial parts of Arctium lappa, Calopogonium mucunoides, Cymbopogon citratus, Baccharis trimera, Equisetum sp., Melia azedarach, Mentha spp., Ricinus communis, Ocimum basilicum, Momordica charantia and Chrysanthemum parthenium. According to Franzener et al. (2007), spraying tomatoes with the aqueous extract obtained from the root ofTagetes patula at dilutions of 1:1, 1:2, 1:3, 1:4 (v:v) (extract:water), barely reduced the number of galls, with results similar to those of untreated plants.

These results indicate that the aqueous extracts of V. officinalis, E. mulungu, Q. amara, B. pilosa and $P$. lanceolata sprayed on tomato shoots, do not control M. incognita. This may suggest that the mode of application was not suitable for this test or that the active principle of the plants were not released to the mode of extraction used (Gardiano et al. 2010).

Moreover, according to Chitwood (2002), the nematicidal effect of plant extracts, when applied to the shoots, become dependent on the absorption of bioactive compounds through the leaves, translocation of these substances and the subsequent release of these compounds by root exudation, and the possibility of the activation of induced resistance in plants. No effect of aerial spraying of tomato plants was observed in this study, may also have occurred by non-systemic activity of the compounds present in the extracts or non-activation of the protective mechanisms of the plant. However, further studies should be conducted to confirm these hypothesis.

\section{Conclusions}

These results showed that under laboratory conditions the aqueous extracts of the plants evaluated at different concentrations reduce hatching of $\mathrm{J}_{2} M$. incognita. Under greenhouse conditions, the aqueous extracts of $V$. officinalis, E. mulungu, $Q$. amara, B. pilosa and $P$. lanceolata, used as foliar sprays showed no effectiveness in controlling $M$. incognita. The efficiency of these extracts to control plant parasitic nematodes during in vitro tests should not be disregarded, however, further studies should be conducted to test different methods of application, doses or methods of extracting the active principles.

\section{References}

Bala, S.K. and N.C. Sukul

1987 Systemic nematicidal effect of eugenol. Nematropica, 17:219-222

Bharadwaj, A. and Sharma, S.

2007 Effect of some plant extracts on the hatch of Meloidogyne incognita eggs. International Journal of Botany, 3(3):312-316.

Campos, V.P.; Souza, J.T. and Souza, R.M.

1998 Controle de fitonematóides por meio de bactérias. Revisão Anual de Patologia de Plantas, v.6, pp.285-327.
Chitwood, D.J.

2002 Phytochemical based strategies for nematode control. Annual Review of Phytopathology, 40:221-249.

Elbadri, G.A.; Lee, D.W.; Park, J.C.; Yu, B.H. and H.Y. Choo 2008 Evaluation of various plant extracts for their nematicidal efficacies against juveniles of Meloidogyne incognita. Journal of Asia-Pacific Entomology, 11:99-102.

Franzener, G.; Martinez-Franzener, A.S.; Stangarlin, J.R.; Furlanetto, C. and K.R.F. Schwan-Estrada 
2007 Proteção de tomateiro a Meloidogyne incognita pelo extrato aquoso de Tagetes patula. Nematologia Brasileira, 31(1):27-37.

Ferraz, S.; Freitas, L.G.; Lopes, E.A. and C.R. Dias-Arieira 2010 Manejo sustentável de fitonematoiodes. Universidade Federal de Viçosa. Viçosa, Minas Gerais, Brasil. Editora: UFV, $245 \mathrm{p}$.

Ferris, H. and L. Zheng

1999 Plant sources of Chinese herbal remedies: effects on Pratylenchus vulnus and Meloidogyne javanica. Journal of nematology, 31(3):241-263.

Freitas, L.G.; Lima, R.D’ARC and Ferraz, S.

2007 Introdução à nematologia. Cadernos didáticos, Universidade Federal de Viçosa. Viçosa, Minas Gerais, Brasil. Editora: UFV, n. 58, 90p.

Gardiano, C.G.; Ferraz, S.; Lopes, E.A.; Ferreira, P.A.; Carvalho, S.L. and Freitas, L.G.

2008a Avaliação de extratos aquosos de espécies vegetais, aplicados via pulverização foliar, sobre Meloidogyne javanica. Summa Phytopathologica, 34(4):376-377.

Gardiano, C.G.; Ferraz, S.; Lopes, E.A.; Ferreira, P.A. and Carvalho, S.L.

2008b Pulverização de tinturas vegetais em tomateiros para o controle de Meloidogyne javanica. Revista Trópica Ciências Agrárias e Biológicas, 2(3):12-22.

Gardiano, C.G.; Ferraz, S.; Lopes, E.A.; Ferreira, P.A.; Amora, D.X. and Freitas, L.G.

2009 Avaliação de extratos aquosos de várias espécies vegetais, aplicados ao solo, sobre Meloidogyne javanica (Treub, 1885) Chitwood, 1949. Revista Semina: Ciências Agrárias, 30(3):551-556.

Gardiano, C.G.; Dallemole-Giaretta, R.; Lopes, E.A.; Zooca, R.J.F.; Ferraz, S. e Freitas, L.G.

2010 Atividade nematicida de extratos de sementes de espécies de Crotalaria sobre Meloidogyne javanica. Revista Trópica- Ciência Agrárias e Biológicas, 4(1):3-7.

Hasabo, A.A. and Noweer, E.M.A.

2005 Manegement of root-knot nematode Meloidogyne incognita on eggplant with some plant extracts. Egypt. J. Phytopathol., 33(2):65-72.

Insunza, V.; Aballay, E. and Macaya, J.

2001 In vitro nematicidal activity of aqueous extracts on Chilean populations of Xiphinema americanm sensu lato. Nematropica, 31(1):47-54.
Javed, N.; Gowen, S.R.; Inam-Ul-Haq, M.; Abdullah, K. and Shahina, F.

2008 Systemic and persistent effect of neem (Azadirachta indica) formulations against root-knot nematodes, Meloidogyne javanica and their storage life. Crop Protection, 26:911-916.

Lopes, E.A.; Ferraz, S.; Freitas, L.G.; Ferreira, P. A. and Amora, D.X. 2005 Efeito de extratos aquosos de mucuna preta e de manjericão sobre Meloidogyne incognita e M. javanica. Nematologia Brasileira, 29(1):67-74.

Lorenzi, H. and Matos, F.J.A.

2008 Plantas medicinais: nativas e exóticas. Nova Odessa: Instituto Plantarum, $512 \mathrm{p}$.

Meyer, S.L.F.; Zasada, I.A.; Roberts, D.P.; Vinyard, B.T.; Lakshman, J.K.L.; Chitwood, D. and Carta, L.K.

2006 Plantago lanceolata and Plantago rugelii extracts are toxic to Meloidogyne incognita but not to certain microbes. Journal of Nematology, 38(3):33-338.

Neves, W.S.; Freitas, L.G.; Dallemole-Giaretta, R.; Fabry, C.F.S.; Coutinho, M.M.; Dhingra, O.D.; Ferraz, S. and Demuner, J.A. 2005 Atividade de extratos de alho (Allium sativum), mostarda (Brassica campestris) e pimenta malagueta (Capsicum frutescens) sobre eclosão de juvenis de Meloidogyne javanica. Nematologia Brasilieira, v. 29:273-278.

Neves, W.S.; Freitas, L.G.; Lopes, E.A.; Coutinho, M.M.; Dallemole-Giaretta, R. and Ferraz, S.

2008 Efeito, in vitro, do extrato de sementes de mamão sobre a eclosão e juvenis de Meloidogyne spp. Revista Trópica - Ciências Agrárias e Biológicas, 2(3):9-14.

Nogueira, M.A.; Oliveira, J.S.; Ferraz, S. and Santos, M.A. 1996 Nematicidal constituents in Mucuna aterrima and its activity on Meloidogyne incognita race 3. Nematologia Mediterrânea, 24:249-252.

Oka, Y.; Nacar, S.; Putievsky, E.; Ravid, U.; Yaniv, Z. and Spiegel, Y. 2000 Nematicidal activity of essential oils and their components against the root-knot nematode. Nematology, 90(7):710-715.

Rocha, F.S.; Muniz, M.F.S. and Campos, V.P.

2005 Coloração de fitonematoides com corantes usados na indústria alimentícia brasileira. Nematologia Brasileira, 29:293-297.

Silva, J.C.T.; Oliveira, R.D.L.; Jham, G.N. and Aguiar, N.D.C. 2008 Effect of neem seed extracts on the development of the soybean cysts nematode. Tropical Plant Pathology, 33(3): 171-179. 
